\title{
O ESTADO CONFESSIONAL E A CIDADANIA NO IPÉRIO LUSO-BRASILEIRO: OS DISPOSITIVOS PENAIS DO TRATADO DE 1810 FACE À CONSTITUIÇÃO DE
}

1822

\author{
CONFESSIONAL STATE AND CITIZENSHIP IN THE LUSO-BRASILIAN EMPIRE: THE \\ CRIMINAL RULES OF THE TREATY OF 1810 IN THE LIGHT OF THE CONSTITUTION
}

OF 1822

\author{
Jairdilson da Paz Silva*
}

\begin{abstract}
RESUMO: A discussão que se gerou entre juristas e políticos na época dos trabalhos constituintes deixava claro que seria impossível deduzir do texto constitucional as noções claras de quem era cidadão, estrangeiro ou outra classe de indivíduos, que residiam dentro das fronteiras do império. Principalmente pelo simples fato de que a natureza e a conotação civilizacional do conceito de cidadania do século XIX eram demasiado elitistas para uma real inclusão. Entretanto, o modelo constitucional em matéria de confesionalidade havia sido o modelo gaditano. Ainda assim, o Tratado de Amizade e Aliança entre Portugal e Grã-Bretanha garantia que as isenções já pactuadas e previstas no Tratado firmado em 1654 seguiriam valendo. Ademais, aquele Tratado contava com uma parte penal, onde eram descritas as infrações em matéria religiosa e as respectivas penas a serem aplicadas, de acordo o caso.
\end{abstract}

PALAVRAS-CHAVE: Constituição de 1822. Cidadania, Confessionalidade. Direito Penal. Tratados de 1810.

\begin{abstract}
The discussion at the time of the constituent work made it clear that it would be impossible to deduce from the constitutional text clear notions of who was the citizen, the foreigner or any another class of individuals residing within the borders of the empire. This impossibility was observed mainly due to the simple fact that the nature and the civilizational connotation of citizenship in the nineteenth century were too elitist for real inclusion. Therefore, the constitutional model that inspired the confessional regulation had been the Constitution of Cadiz. Despite these facts, the Treaty of Friendship and Alliance between Portugal and Britain guaranteed that the exemptions already agreed in the Treaty signed in 1654 were still in force. Moreover, that treaty had a section that regulated criminal issues, in which infringements on religious matters and their respective penalties, according to the case, were described.
\end{abstract}

KEYWORDS Constitution of 1822. Citizenship. Confessional. Criminal Law. Treaty of 1810.

SUMÁRIO: Introdução. 1 Cidadania e critérios confessionais: a constitucionalização da soberania nacional. 1.1 A Constituição de 1822: a definição do cidadão com liberdade de consciência e a dualidade cidadã de Siéyès. 1.2 O Tratado de Amizade e Aliança entre Portugal e GrãBretanha: a extraterritorialidade e os dispositivos penais. 1.3 As discussões no Parlamento sobre a liberdade de consciência dos estrangeiros no gozo dos direitos de cidadãos: "contentar aos estrangeiros e contentar a religião" - a equação de difícil fórmula. Conclusão. Referências.

\section{INTRODUÇÃO}

A formação do Império português se deu sobre uma base cristã/católica que se impôs ao conceito mesmo de cidadão que se conformaria em ambiente constitucional. Houve discussões entre juristas e políticos no momento dos trabalhos constituintes, onde se deixou explicito que uma dedução simples e direta do texto de quem era cidadão, ou qual o papel do

\footnotetext{
* Pós-doutor em História do Direito Constitucional pela Universidad de Salamanca, Espanha. Doutor em História do Direito Constitucional pela Universidad de Salamanca, Espanha. Mestre pela Università Degli Studio di Milano e Università Degli Studio di Messina, Itália. Mestre pela Universidad Internacional de Andalucia e Universidad de Huelva, Espanha. Pós-graduado em Direitos Humanos pela Universidad de Salamanca, Espanha. Licenciado em História pela Universidade Federal da Bahia (UFBA).
} 


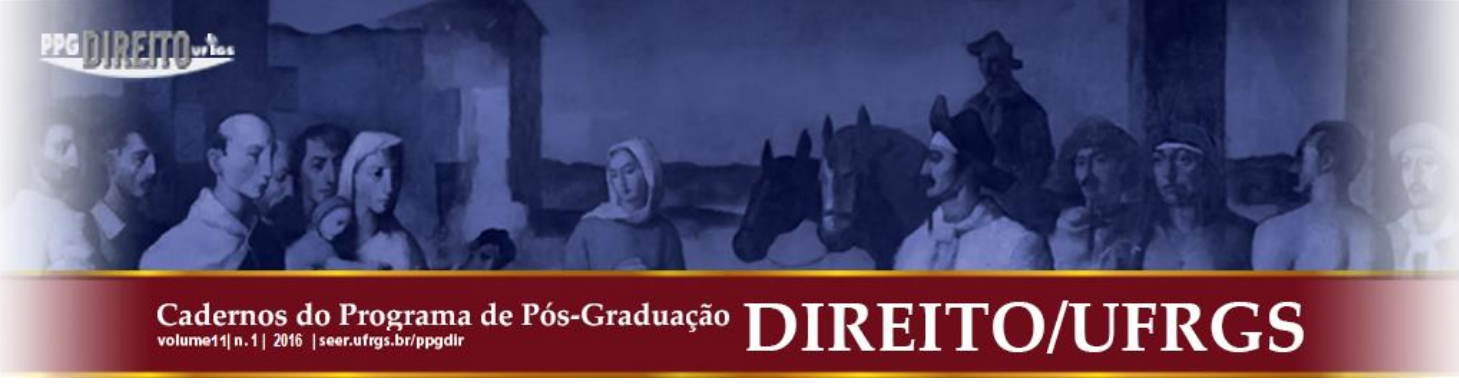

estrangeiro acatólico no texto constitucional e na sociedade de então, não passaria. O conceito de cidadão sofre alguma simbiose no XIX, dado que a natureza e a conotação civilizacional emolduravam, como fronteiras nem sempre fixas, a elitização do termo. A priori, a Constituição de Cádiz foi o farol constitucional em matéria de confessionalidade para o império em questão. Portanto, quando se assina o Tratado de Amizade e Aliança em 1810, as garantias e isenções pactuadas vão se impor ao texto constitucional Luso-brasileiro aprovado em 1822. E para que tais disposições pudessem conviver em um universo católico, aceitas por pressões econômicas e geopolíticas, um conjunto de dispositivos penais passaram a conformar o texto do tratado, onde o acatólico se defrontava com regras infracionais em matéria religiosa, com as respectivas penas a serem aplicadas, com escopo a impedir o proselitismo protestante. Isto gera uma matização à imposição confessional da cidadania que destoa da inspiração gaditana.

O Império português se expandiu com a meta da cristianização da conquista, fazendo com que a construção da identidade portuguesa se fizera pela força, à dimensão providencial e messiânica. A catolicidade foi promovida a elemento de identidade no Império, mas, também é verdade que foi um elemento destrutivo desta mesma unidade. Dado que a mera conversão não satisfazia como elemento aglutinador da busca pela homogeneização do Império. "Portugal, nação fidelíssima, tinha como principal missão combater os infiéis e dilatar a fé de Cristo". No estatuto colonial faltava o cariz da unificação desde as mais diversas facetas. Assim que eram considerados "naturais" os nascidos de pais portugueses, segundo as Ordenações Filipinas (II, 55), e por tanto gozavam do estatuto pleno de ser português, usavam o direito português e se sujeitavam à justiça portuguesa. Enquanto isso, havia no império os que eram considerados como estrangeiros, liberados da obediência ao governo e ao direito português. Desta forma estavam considerados os "sobas amigos, más não vassalos" de

\footnotetext{
1 A estratégia portuguesa era, principalmente no caso que nos interessa mais, o Brasil, cristianizar para homogeneizar a conquista e o império. Más se mostrou um verdadeiro fracasso, como destaca Ronald Raminelli, no caso dos povos tupinambás do Brasil. Para saber mais leia-se em RAMINELLI, Ronald. Império da fé: Ensaio sobre os portugueses no Congo, Brasil e Japão. In: FRAGOSO, João; BICALHO, Maria Fernanda; GOUVÊA, Maria de Fátima (orgs.). O Antigo Regime nos trópicos. A dinâmica imperial portuguesa (Séculos XVI-XVIII). Civilização Brasileira. Rio de Janeiro, 2001, p. 245 e ss.
} 


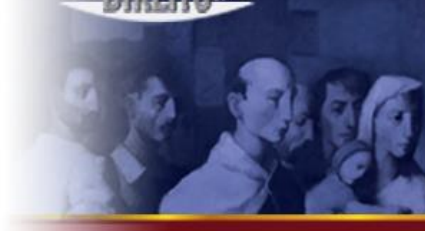

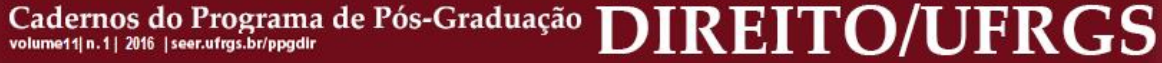

Angola $^{2}$ - aos quais fazia referência o Regimento dos Governadores - e os "índios bravos" brasileiros ${ }^{3}$.

Entretanto, houve, segundo Fernando Catroga, uma "estatização" do cristianismo a partir do século XVI, fruto da aliança entre o trono e o altar para justificar o poder absoluto dos monarcas. O princípio fixado no Tratado de Westfalia, firmado em 1649, depois das guerras religiosas, era o de "une roi, une foi, une loi", que era estabelecida como uma premissa para a salvação coletiva. Esta também será a justificativa para a revogação do apaziguador Edito de Nantes em 1685. A crescente simbiose do poder temporal ao imiscuir-se nos assuntos da igreja, faz com que os monarcas assumam o papel central para impor as premissas de Westfalia. A necessidade de sedimentar o poder vai impor a necessidade de criar uma "patria communis", que o Estado-Nação precisará mais que nunca, para sustentar que exista uma "pátria grande", e fará falta para isso, uma unidade legal, religiosa e linguística. Assim que a heterogeneidade ficou fora dos planos, em um império multifacetado: cultural, linguística e religiosamente ${ }^{4}$.

As teorias do contrato social, em palavras de Fernando Catroga, secularizaram os conceitos de soberania do Estado, desenvolvido por Jean Bodin, como também o sentido do poder constituinte que passará a residir no "Povo" ou na nação, de acordo ao sistema constitucional. O direito de resistência frente ao soberano, ao poder absoluto, passa pela modernização e aplicação nos movimentos revolucionários tanto nas Colônias Anglo-saxãs da América, como na França. Ali se verá por primeira vez plasmar-se em um documento escrito os direitos e deveres dos cidadãos. Portanto, se constitucionalizam tais direitos, posto que não só são declarados senão que se estabelecem os instrumentos de proteção a estes mesmos direitos. Dado que as teorias contratuais (Locke, Hobbes, Rousseau), e a presença do jusnaturalismo vão declarar e compor estes direitos, enquanto que a teorização da divisão dos poderes do Estado (Montesquieu) vai ser a garantia de sobrevivência e aplicação destes

\footnotetext{
2 SILVA, Cristina Nogueira da. A cidadania nos Trópicos. O Ultramar no constitucionalismo monárquico português (c. 1820-1880). Lisboa: Dissertação de doutoramento apresentada à Universidade Nova de Lisboa (Faculdade de Direito), 2004, p. 28 e ss.

${ }^{3}$ HESPANHA, Antônio Manuel. A constituição do Império português. Revisão de alguns enviesamentos correntes. In: FRAGOSO, João; BICALHO, Maria Fernanda; GOUVÊA, Maria de Fátima (orgs.). O Antigo Regime nos trópicos. A dinâmica imperial portuguesa (Séculos XVI-XVIII). Civilização Brasileira. Rio de Janeiro, 2001, p. 170 e ss.

${ }^{4}$ CATROGA, Fernando. Em nome da Nação. In: CATROGA, F.; ALMEIDA, Pedro Tavares de (Cords.). Res Pública: Cidadania e representação política em Portugal, 1820-1826. Biblioteca Nacional de PortugalAssembleia da República: Lisboa, 2010, p. 22 e ss.
} 


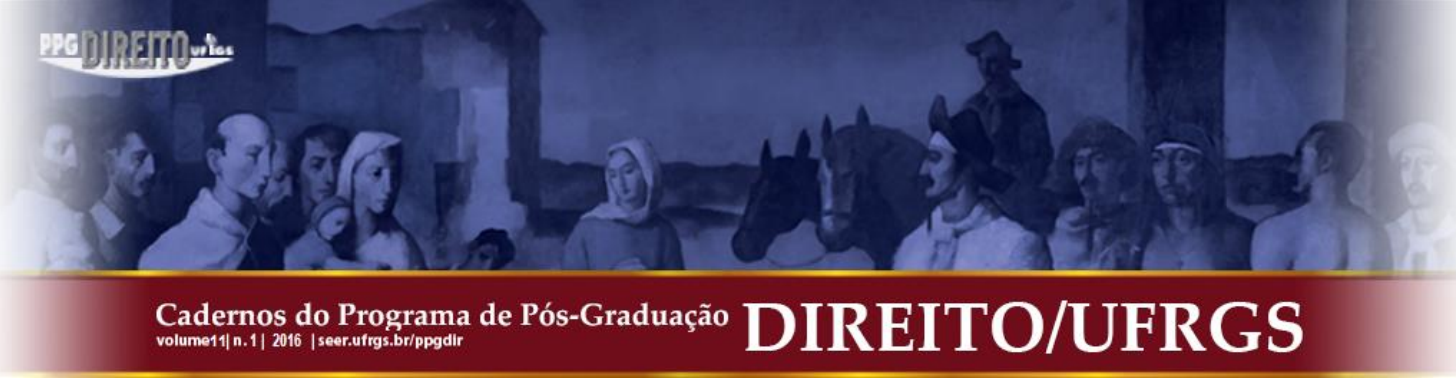

mesmos direitos dos cidadãos ${ }^{5}$. Será tanto Rousseau como Locke quem estarão presentes naqueles processos revolucionários descritos, como também os passados na península ibérica, dado que são tributários do processo francês ${ }^{6}$. É verdade que para concretizar a secularização do Estado, sempre se sofreu um antagonismo das religiões históricas e, sobretudo, da Igreja Católica. "Se pode dizer que, nesta experiência, na herança da religião civil de Rousseau se desenvolveu todas suas potencialidades para transformar numa estrita religião política (...)", ademais, “o Estado não se limitará a uma atitude de indiferença diante dos que consideravam seus adversários, más reagia para conseguir nacionalizar às consciências"7.

\section{CIDADANIA E CRITÉRIOS CONFESSIONAIS: A CONSTITUCIONALIZAÇÃO DA SOBERANIA NACIONAL}

A constitucionalização da soberania nacional fui $o$ reflexo das teorias da autossuficiência do Estado e foi potencializado pelas teorias do contrato social. Siéyès, quando escreve, o celebre ensaio Quest-ce que le tiers état? em1789, demostrará uma interconexão entre as concepções de soberania popular e soberania nacional, prognosticando uma anterioridade da relação entre governantes e governados, dado que o poder constituinte estava identificado com a nação inteira, e o "Povo" identificado com os governados. Estas ideias, para Catroga, se refletiram na Declaração de 1789, na tentativa de evitar uma fragmentação corporativa semelhante ao do Antigo Regime: "A origem de toda soberania reside essencialmente na Nación. Nenhum órgão, nem nenhum indivíduo pode exercer autoridade que não emane expressamente dela" (art. 3) ${ }^{8}$. Este mesmo princípio passará à Constituição francesa de 1791, igualmente no artigo $3^{\circ}$, como também aos

\footnotetext{
${ }_{6}^{5}$ Idem. p. 24.

6 "Devido ao peso francês nos processos revolucionários, em particular nos de Espanha e Portugal, ir-se-á dar relevo a Rousseau. Como outros contratualistas (Hobbes, Locke), o autor das Confissões também pensava que a ausência de autoridade conduziria ao estado de guerra. Daí a necessidade de os indivíduos se associarem para superar a precariedade do seu estado de natureza. Todavia, para ele (ao contrário de Locke), a sociabilidade não era uma característica pré-existente ao contrato, mas fruto do consentimento de seres livres. E seria contraditório que cada indivíduo detivesse uma autoridade natural sobre o outro. Só a convenção, baseada na vontade unânime de todos, legitimaria um pacto social que possibilitasse a liberdade recíproca dos seus membros, organizados em comunidade política". Ibidem.

${ }^{7}$ CATROGA, Fernando. Entre deuses e césares. Secularização, laicidade e religião civil. 2. ed.. Coimbra: Almedina, 2010, p. 223 e ss.

${ }^{8}$ DECLARATION DE DROITS DE L'HOMME ET DU CITOYEN (1789). Art. $3^{\circ}$. "Le principe de toute souveraineté réside essentiellement dans Ia nation. Nul corps, nul individu ne peut exercer d'autorité qui n'en émane expressément".
} 


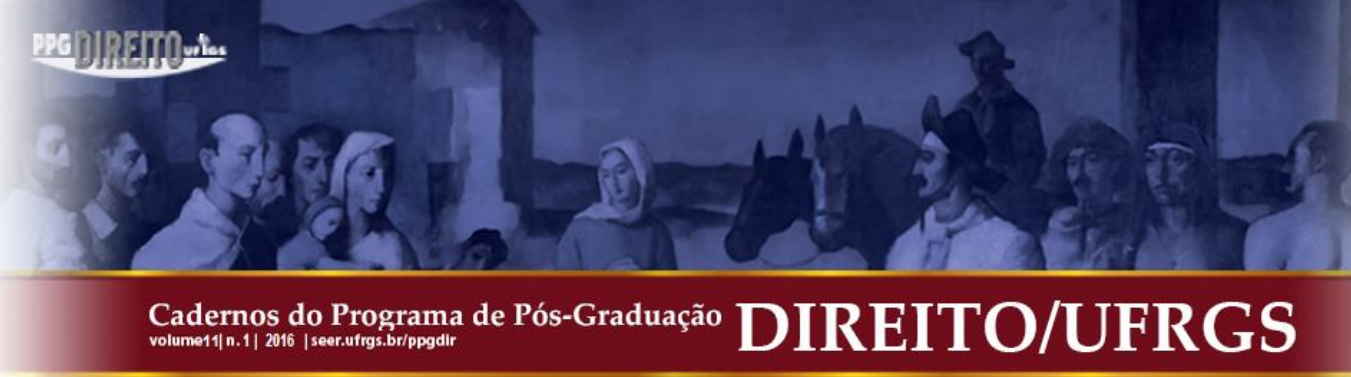

constitucionalismos de influência francesa, como a Constituição espanhola de 1812, a portuguesa de $1822^{9}$, assim como a brasileira de 1824 .

É intrínseco à génesis do Estado Moderno, segundo Zília Osório de Castro, a centralização desde a visão do poder, o que vai provocar uma confrontação entre o Estado e a Igreja. Em Portugal, para aquela autora, se notarão duas fases daquela relação: a primeira na fase pombalina, o paralelismo de poder que exercia a igreja rivalizando com o poder do próprio Estado dentro de sus fronteiras parecia inaceitável e conflituosa. Mitigando sobre maneira a noção de soberania do Estado à época. Já na segunda fase, no âmbito da concepção liberal vintista o poder religioso será visto como um poder inerente à concepção mesma de Estado, ou seja, um instrumento ao serviço do Estado. Deste modo, o sentimento religioso defendido em sua sacralidade, seria confrontado com uma dimensão laica, quando posto no âmbito da perspectiva política ${ }^{10}$.

Com base no art. $3^{\circ}$ da Declaração francesa podemos conectar a discussão estabelecida, tendo como referência os estudos do professor Manuel Hespanha, com as permanências do Antigo Regime e as inovações liberais que se refletirão na Constituição vintista ${ }^{11}$. Em flagrante contradição analisamos o art. 26 da Constituição portuguesa, inspirado na Declaração francesa, aprovada pela Assembleia Nacional, em 26 de agosto de 1789, que dirá: “A soberania reside essencialmente na Nação. Não pode, portanto, ser exercitada senão por seus representantes legalmente eleitos. Nenhum indivíduo ou corporação exerce autoridade pública, que não derive da mesma Nação"; e o art. 25, da mesma constituição, onde se declara a confesionalidade da Nação portuguesa. Como dirá aquele professor, a soberania seguia guardando determinados déficits, como se verá no âmbito do art. 25, que institui que: “A Religião da Nação Portuguesa é a Católica Apostólica Romana. Ainda que se permita aos estrangeiros o exercício particular de seus respectivos cultos" ${ }^{\prime 12}$. Esta opinião de respeitar aos

\footnotetext{
${ }^{9}$ CATROGA, Fernando. op. cit., p. 27 e ss.

10 "Daí, enfim, a complexidade de uma evolução marcada por tensões mais ou menos profundas a nível ideológico, institucional, político e religioso, encaradas como incidências particularizadas de um mesmo movimento cultural”. CASTRO, Zília Osório de. Cultura e Política. Manuel Borges Carneiro e o Vintismo. v. II. Lisboa: Instituto Nacional de Investigação Cientifica, Universidade Nova de Lisboa, 1990, p. 587.

${ }^{11}$ HESPANHA, A. M. Guiando a mão invisível. Direitos, Estado e Lei no Liberalismo Monárquico Português. Coimbra: Almedina, 2004, p. 90 e ss.

12 "Esta disposição he, não só incompatível com o princípio da tolerância, principio essencial em um systema verdadeiramente constitucional, mas além d’isso inexequível. Ninguém sobre a terra tem direito para prescrever aos cidadãos portugueses que pensem de tal ou tal modo em matéria de religião. Ninguém lhe pode prohibir quaisquer práticas que se chamem religiosas, quer profanas, uma vez que elas não ofendam nem a liberdade, nem a propriedade, ou o bom nome de alguém”. FERREIRA, Silvestre Pinheiro. Breves observações sobre a
} 


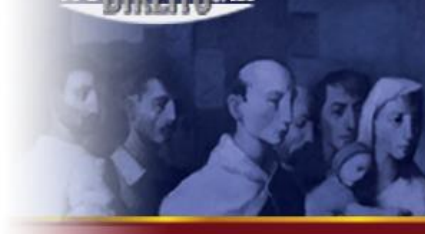

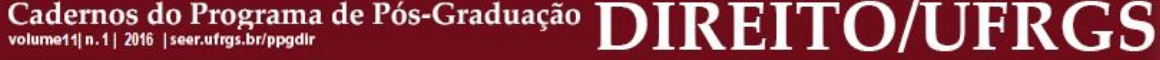

estrangeiros a liberdade de culto, más com restrições, figura no art. $8^{\circ}$ de um projeto constitucional que aparece no ano de 1821, assinado por um Lusitano Filantropo ${ }^{13}$.

Destacadamente se nota um poder externo que se imiscui na máxima do art. 26; a Religião Católica Apostólica Romana é apresentada pela mesma constituição como o elemento, ou corporação, que vulnera à autossuficiência da soberania da Nação. Assim também passa com a cidadania, dado que no art. 19 da Constituição vintista se fixava como um dos principais deveres desta, o de venerar à Religião ${ }^{14}$. Não que com isto chegasse a desnaturalizar aos não católicos ${ }^{15}$. Más, não era somente nesta matéria onde a soberania cedia passo. No art. $8^{\circ}$ se previa ceder a apreciação dos abusos da liberdade de imprensa em matéria religiosa à censura episcopal. Como também se previa celebrar, para marcar o início dos trabalhos das assembleias eleitorais, uma missa ao Espírito Santo (art.52), como nos demais atos eleitorais (art. 70). Se institui, ademais, que no juramento - sobre os Santos Evangelhos do rei, dos deputados eleitos e dos Conselheiros de Estado, por encima de tudo, estava o compromisso de manter a Religião Católica Apostólica Romana (arts. 78, 126 y 166). Mais ainda, a Constituição começava em seu preâmbulo com a invocação do "Nome da Santíssima e Indivisível Trindade"16. E onde o rei terá o tratamento de "Majestade Fidelíssima" no art. 127.

A fórmula de sanção às leis dada pelo rei, prevista no art. 113: "Dom F... pela graça de Deus e pela Constituição da Monarquia (...)", fazia com que "se incluísse na titulação régia

Constituição Política da Monarchia Portugueza decretada pelas Cortes Geraes Extraordinarias e Constituintes reunidas em Lisboa no anno de 1821. Paris: Rey E. Gravier, 1837, p. 9.

13 "Sobretudo estabeleçamos boa educação e instrução, pois que os fins procedem dos princípios: e como felizmente professamos a Religião Catholica Romana, as mais sejam toleradas quanto aos estrangeiros sem sinal exterior de culto, mas o público sustente só àquela e os seus ministros”. Fantasias Constitucionaes, seguidas por algumas reflexões, da Razão, e da Experiência, publicadas por um Lusitano Filantropo. Lisboa: Imprensa Nacional, com licença da Comissão de Censura, 1821, p. 5.

${ }^{14}$ Silvestre Pinheiro Ferreira vê nestes conselhos de moral como impróprios da legislação. FERREIRA, Silvestre Pinheiro. Breves observações sobre a Constituição Política da Monarchia Portugueza decretada pelas Cortes Geraes Extraordinarias e Constituintes reunidas em Lisboa no anno de 1821. Paris: Rey E. Gravier, 1837, p. 17; está republicada em HESPANHA, A. M.; SILVA, Cristina Nogueira da (dir.). Fontes para a história constitucional portuguesa. Lisboa: Faculdade de Direito da Universidade Nova de Lisboa, 2004 (Sitio da Biblioteca Nacional, Lisboa).

${ }^{15}$ HESPANHA, A. M. op. cit., p. 90 e ss.

${ }^{16}$ Para Silvestre Pinheiro Ferreira esta invocação é uma incongruência por parte de uma Asamblea Legislativa que não pretende derivar seu poder do chamado direito divino; e é inútil, porque não influi no cumprimento da constituição". FERREIRA, Silvestre Pinheiro. Breves observações sobre a Constituição Política da Monarchia Portugueza decretada pelas Cortes Geraes Extraordinarias e Constituintes reunidas em Lisboa no anno de 1821. Paris: Rey E. Gravier, 1837, p. 1; está republicada em HESPANHA, A. M.; SILVA, Cristina Nogueira da (dir.). Fontes para a história constitucional portuguesa. Lisboa: Faculdade de Direito da Universidade Nova de Lisboa, 2004 (Sitio da Biblioteca Nacional, Lisboa). 


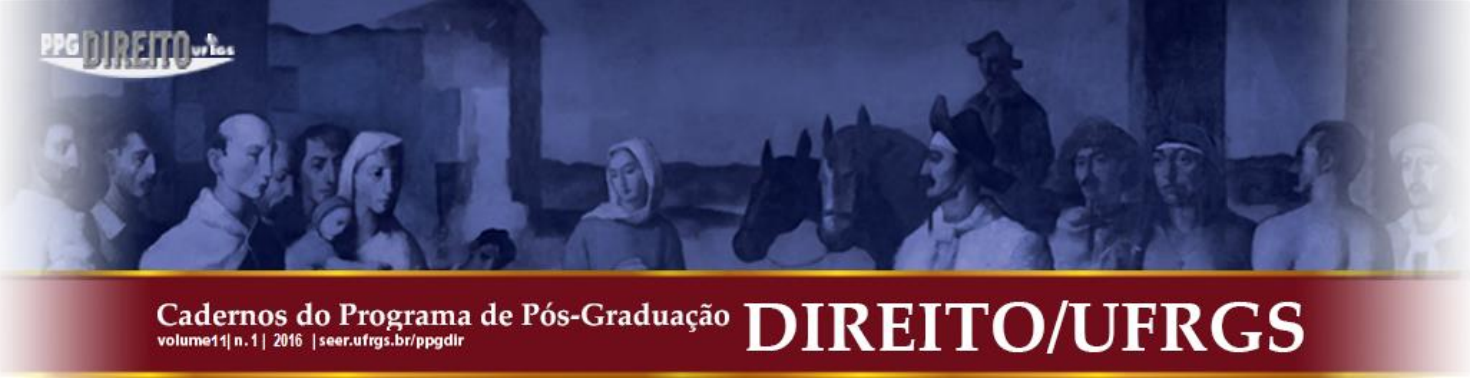

Nos dirá Cristina Nogueira da Silva que, ao declarar a religião católica como religião oficial do Estado, e ao omitir os problemas relacionados com o pluralismo religioso das sociedades ultramarinas, o texto constitucional português conduzirá a uma série de indefinições e incertezas existentes ao redor da própria definição de cidadania e da nacionalidade do universo das populações autóctones do ultramar português, não católicas. Apesar de que houvesse adotado como critério para fixar a cidadania o ius solis em detrimento do ius sanguinis ${ }^{20}$.

Está claro que aqui não buscaremos tratar todas e cada uma das partes e problemas do Império português na temática da cidadania relacionada com o problema da confessionalidade do Estado, senão que, pelo contrário, trataremos de redefinir e direcionar a discussão para o que tange a parte americana do Império, sobretudo o Brasil.

\subsection{A Constituição de 1822: a definição do cidadão com liberdade de consciência e a dualidade cidadã de Siéyès.}

A discussão que se gerou entre juristas e políticos na época dos trabalhos constituintes deixava claro que seria impossível deduzir do texto constitucional as noções claras de quem era cidadão, estrangeiro ou outra classe de indivíduos que residia dentro das fronteiras do império. Principalmente pelo simples fato de que a natureza e a conotação civilizacional do conceito de cidadania do século XIX eram demasiado elitistas para uma real inclusão. Ademais, o conceito de "Nação", para tais juristas e políticos, era a de uma associação voluntária, um conjunto de indivíduos unidos pela adesão de um mesmo "contrato social", ainda que não se levasse em conta a cor da pele, a cultura ou a religião ${ }^{21}$. Isto estava nos discursos, mas era muito diferente na prática. Silvestre Pinheiro Ferreira ao analisar o art. 21 da Constituição portuguesa dirá que fazer diferença entre a fruição ou não dos direitos civis

\footnotetext{
20 SILVA, Cristina Nogueira da. Liberdade e tolerância religiosa: "portugueses não católicos" no ultramar do século XIX. Historia Constitucional. n. 8, 2007, p. 42. Disponível em: <http://hc.rediris.es/08/index.html>. Acessado em: 18 jan. 2016 Ademais, os problemas relacionados à cidadania neste período foram discutidos amplamente em SILVA, Cristina Nogueira da. A cidadania nos Trópicos. O Ultramar no constitucionalismo monárquico português (c. 1820-1880). Tese de doutorado apresentada à Universidade Nova de Lisboa (Faculdade de Direito), Lisboa, 2004. Acerca da administração portuguesa em África, principalmente em Angola, veja-se o trabalho de SANTOS, Catarina Madeira. Um governo "polido" para Angola, reconfigurar dispositivos de domínio (1750-c. 1800). Tese de doutorado apresentada à Universidade Nova de Lisboa (Faculdade de Ciências Sociais e Humanas). Lisboa, 2005.
}

${ }^{21}$ SILVA, Cristina Nogueira da. op. cit., p. 42 e ss. 


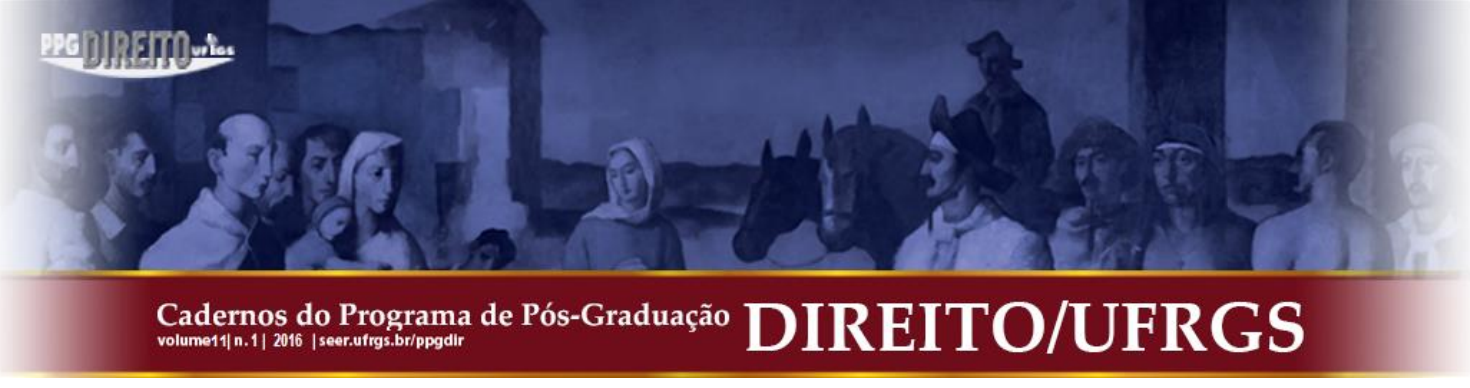

por nacionais e estrangeiros, seria inútil, dado que todos devem ter estes direitos. Mas, quanto aos direitos político

A sua importância é tal, que seria barateá-los conferir o exercício deles a alguém, só porque nasceu em tal, ou tal pais, e de tais, ou tais pessoas. Estas circunstâncias não têm ligação alguma com as condições de capacidade. Outras são as provas que a lei deve exigir, quer dos nacionais, quer dos estrangeiros, para eles poderem exercer aqueles direitos políticos. ${ }^{22}$

Assim, Silvestre Pinheiro Ferreira, no Título II (Dos Direitos Civis), Capítulo I (Das Garantias Individuais), do Projeto de Lei Fundamental de sua autoria, se pronuncia deste modo sobre a liberdade de consciência:

Art. 17 - Em virtude do direito de liberdade, e nos termos do artigo 13, é licito ao cidadão: parágrafo I. - Professar quaisquer doutrinas religiosas e praticar quaisquer atos de culto externo, segundo os ditames da própria consciência ${ }^{23}$

Ao mais puro estilo revolucionário francês, o publicista português propõe uma liberdade de consciência. E de uma maneira mais tolerante, no projeto de Leis Orgânicas, na Parte I, Capítulo V (Da Naturalização dos Estrangeiros), no art. 478, trata do processo de naturalização dos estrangeiros ${ }^{24}$, o que está bastante ao estilo liberal. Em realidade, "a Nação portuguesa era por eles (juristas e políticos) identificada desde um registro duplo, como um contrato, más também como uma comunidade orgânica, um conjunto de pessoas ligadas pela mesma língua, cultura, genealogia e religião. Era também uma comunidade afetiva, baseada nos laços que ligavam os cidadãos portugueses à comunidade, privilegiando os sentimentos de amor, fidelidade e implicação moral, facilitados pela convivência histórica e intergeneracional. No Ultramar, onde viviam pessoas com hábitos, costumes, religião e raças diferentes, não era fácil saber quem era ou não era português"25.

\footnotetext{
${ }^{22}$ FERREIRA, Silvestre Pinheiro. op. cit., p. 7 e 8.

${ }^{23}$ FERREIRA, Silvestre Pinheiro. Projeto de Código Político para a Nação Portugueza. Ministro de Estado honorário, sócio da Academia das Sciencias de Lisboa e correspondente do Instituto de França. Paris: Casa de Rey; Gravier; J. P. Aillaud, 1838, p. 6.

${ }^{24}$ Idem. p. 126.

${ }^{25}$ SILVA, Cristina Nogueira da. op. cit., p. 42 e ss. Veja-se também em SOBRAL, José Manuel. O Norte, o Sul, a raça, a nação - representações da identidade nacional portuguesa (séculos XIX-XX). Análise Social. v. XXXIX, no 171,2004 , p. 277 e ss.
} 


\title{
Wh

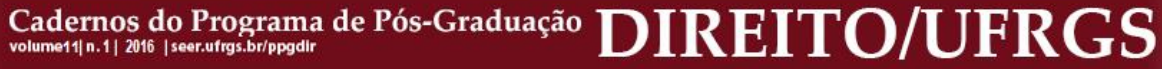

\subsection{O Tratado de Amizade e Aliança entre Portugal e Grã-Bretanha: a extraterritorialidade e os dispositivos penais.}

Como já pudemos constatar, o modelo constitucional em matéria de confessionalidade havia sido o modelo gaditano (Constituição de Cádiz), ainda que bem mais intolerante que o texto português. Era assim, porque Portugal tem uma construção histórica diferente da espanhola, como se pode imaginar, como também é importante ressaltar os tratados de 1810 firmados quando do desembarque do rei D. Joao VI, então príncipe regente, com Inglaterra, que previa a liberdade de culto para os ingleses no território do império português, destacadamente no Brasil, onde se encontrava a Corte nestes momentos. O Tratado de Amizade e Aliança entre Portugal e Grã-Bretanha garantia que o Tribunal da Inquisição continuaria sem ter jurisdição sobre a porção americana dos domínios portugueses e que os vassalos britânicos seguiriam gozando das isenções já pactuadas, e previstas no art. $5^{\circ}$ do Tratado de Westminster firmado em julho de $1654^{26}$. Entretanto, é o Tratado de Comércio e Navegação, também de 1810, a norma que garantia a liberdade de consciência aos súditos de sua majestade britânica, com a seguinte dicção:

\begin{abstract}
Art. XII. Sua Alteza Real O Príncipe Regente de Portugal declara e se obriga no seu próprio Nome, e no de Seus Herdeiros e Sucessores, a que os Vassalos de Sua Majestade Britânica residentes nos seus Territórios, e Domínios não serão perturbados, inquietados, perseguidos, ou molestados por causa da Sua Religião, mas antes terão perfeita liberdade de Consciência, e licença para assistirem, e celebrarem o Serviço Divino em honra do Todo Poderoso Deus, quer seja dentro de suas Casas particulares, quer nas suas particulares Igrejas, e Capelas, que Sua Alteza
\end{abstract}

\footnotetext{
${ }^{26}$ A GENERAL COLLECTION OF Treatts of Peace and Commerce, Renunciations, Manifestos, and other Publick Papers, from the Year 1642, to the End of the Reign of Queen Anne. v. III. LONDON: J. J. and P. Knapton, J. Darby; T. Uibwihter; A. Ward; A. Bettesworth and C. Hitch; J. Pemberton, J. Osborn and T. Longman; C. Rivington; F. Clay; J. Batiey; R. Hbit, and T. Hatchstt, M.DCC.XXXII (1732), p. 99.

CARTA DE LEI DE 26 DE FEVEREIRO DE 1810. Ratifica o Tratado de Amizade e Aliança entre o Príncipe Regente de Portugal e El'Rey do Reino Unido da Grande Bretanha e Irlanda, assinado no Rio de Janeiro a 19 desde mês e ano. Art. IX. Não se tendo até aqui estabelecido, ou reconhecido no Brazil a Inquisição, ou Tribunal do Santo Officio, Sua Alteza Real O Príncipe Regente de Portugal guiado por uma illuminada e liberal Política aproveita a opportunidade que Lhe offerece o Presente Tratado, para declarar espontaneamente no Seu Próprio Nome, e nos Seus Herdeiros e Successores, que a Inquisição não será para o futuro estabelecido nos Meridionaes Domínios Americanos da Coroa de Portugal. Sua Majestade Britannica em consequência desta Declaração da Parte de Sua Alteza Real o Príncipe Regente de Portugal, se obriga da Sua Parte, e declara, que o Quinto Artigo do Tratado de mil seiscentos cincoenta e quatro, em virtude do qual certas Isenções da Autoridade da Inquisição eram concedidas exclusivamente aos Vassallos Britannicos, será considerado como nullo e sem ter efeito nos Meridionaes Domínios Americanos da Coroa de Portugal. E Sua Magestade Britânica consente que esta abrogação do Quinto Artigo do Tratado de mil seiscentos cincoenta e quatro, se estenderá também a Portugal, no caso que tenha logar a abolição da Inquisição naquele País por Ordem de Sua Alteza Real o Príncipe Regente, e geralmente a todas as outras Partes dos Domínios de Sua Alteza Real, onde venha a abolir-se para o futuro aquelle Tribunal.
} 
Real agora, e para sempre, graciosamente lhes concede a permissão de edificarem, e manterem dentro dos seus domínios. (...). De mais estipulou-se, que nem os Vassalos da Grande Bretanha, nem outros quaisquer Estrangeiros de Comunhão diferente da Religião Dominante nos Domínios de Portugal, serão perseguidos, ou inquietados por matérias de Consciência tanto nas Suas Pessoas como nas Suas Propriedades, em quanto eles conduzirem com Ordem, Decência, e Moralidade, e de uma maneira conforme aos usos do País, e ao Seu Estabelecimento Religioso, e Político $^{27}$.

Também neste Tratado, que previa reciprocidade para os cidadãos portugueses em matéria religiosa em Grã-Bretanha, conta igualmente com uma parte onde descreve a aparência que devia ter a igreja de fé protestante e proibia o uso das campanas para marcar a hora dos serviços religiosos. Outrossim, contava o art. XII de uma parte penal, onde se descrevia as infrações em matéria religiosa e as respectivas penas a serem aplicadas, de acordo ao caso.

Assim que, no caso de incumprimento, por parte dos cidadãos britânicos, com o dever de respeitar à religião oficial do Estado, estavam previstas várias punições. Ainda que os mesmos tratados firmados entre o rei português e o rei britânico previam a extraterritorialidade para os cidadãos britânicos, isto é, teriam juízes e jurisdição próprios. Entretanto, no caso de que façam proselitismo, os britânicos que assim delinquirem, poderão ser mandados sair do país, onde a ofensa fora cometida. Também previa que os que em público se portassem com falta de respeito ou com improbidade com os ritos e cerimônias da Religião católica dominante, para estes será chamada a Policia Civil, que poderá castigar com multas ou prisão domiciliar. E em caso de que a ofensa seja muito grave, e tão avultada que perturbe a tranquilidade pública, e ponha em perigo a segurança das Instituições da Igreja, e do Estado, estabelecidas pelas leis, para estas pessoas que fossem autoras de tais ofensas, em existindo provas de fato, poderá ser mandada sair dos domínios de Portugal. Se pacta também, de forma recíproca, que os portugueses lhes permitirão aos britânicos que levem a cabo seus funerais, em lugares convenientes para isto, sem que se lhes perturbem, por motivo quaisquer, os ditos funerais ou as sepulturas dos $\operatorname{mortos}^{28}$.

Nas Bases da Constituição portuguesa, aprovadas em 1821, já previa em seu art. 17 que a Religião Católica Apostólica Romana seria a religião da Nação portuguesa, discutida e

\footnotetext{
${ }^{27}$ CARTA LEI DE 26 DE FEVEREIRO DE 1810. Ratifica o Tratado de Comercio e Navegação entre o Príncipe Regente de Portugal e El'Rey do Reino Unido da Grande Bretanha e Irlanda assinado no Rio de Janeiro aos 18 deste mês e ano.

${ }^{28}$ Idem. Art. XII do Tratado.
} 


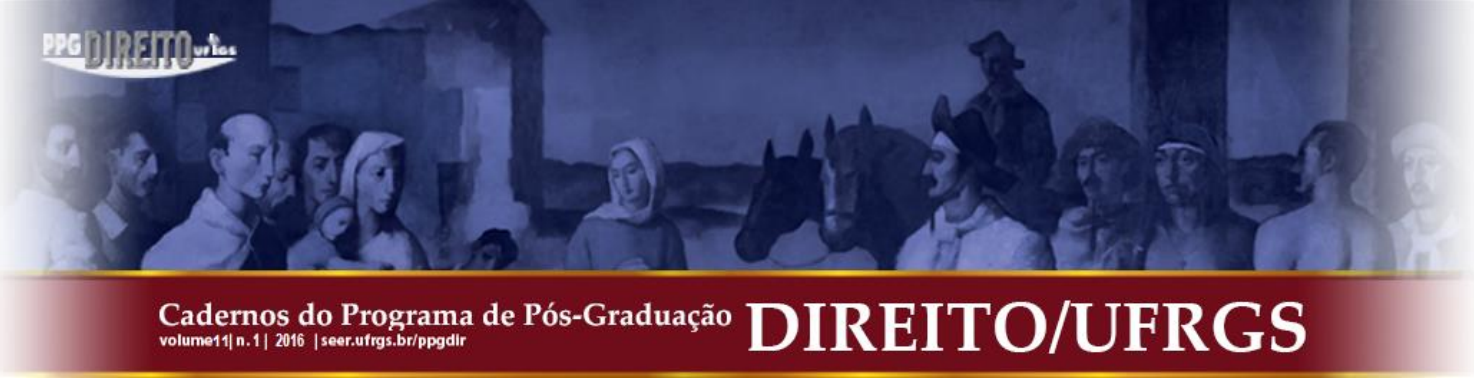

aos estrangeiros o exercício dos respectivos cultos, mas, matizava que existe esta obrigação prevista nos tratados e concessões legais que permitam aos estrangeiros o livre exercício de seu culto. Outrossim, opinava que a religião católica era uma religião de concórdia, desde sua condição de bispo, assim vai dizer que:

\begin{abstract}
Não me oponho à tolerância, pelo contrário sempre sustentei que a tolerância civil se ajuste com o espirito, e máximas do cristianismo. A religião cristã proscreve os erros, mas ela nos ensina a suportar os errantes, pois a sua base é a caridade. Não é uma religião de discórdia, como falsa, e temerariamente Rousseau a descreve no seu contrato social: pelo contrário ela tende a reunir todos os homens, ensinando-nos que todos são irmãos, impondo-nos uma rigorosa obrigação de obedecer às autoridades legítimas, ainda que sejam heterodoxas, e perseguidoras. Ela não quer conquistar senão pela persuasão ${ }^{31}$.
\end{abstract}

Opinião interessante trouxe o ilustríssimo deputado, Sr. Antônio Pereira; primeiro com uma constatação assaz importante de que ao declarar como Religião oficial a Católica, se deduzia que todo português devesse professar dita religião, e em segundo lugar, igualmente se deve inferir que nenhum português pode adotar outra religião diferente desta, que a Nação autoriza. Assim que pensava que o artigo devesse ser redatado de forma ainda mais intolerante, com a seguinte dicção:

A Religião da Nação Portuguesa é a Católica Apostólica Romana, deixa conseguintemente de ser cidadão Português aquele que a não professar; poderá, contudo, permitir-se aos estrangeiros o exercício particular dos seus respectivos cultos: desta maneira o artigo fica mais completo, e expressivo, e a Religião mais eficazmente garantida ${ }^{32}$.

Para o Sr. Deputado Luís Monteiro, havia um problema de proporções muito maiores, prevista na relação, que era o de declarar cidadão ao estrangeiro naturalizado e ao mesmo tempo declarar a confessionalidade da Nação. Dado que a equação não parecia tão simples, como opinavam alguns deputados, posto que, contemplar aos estrangeiros e contentar à religião no texto constitucional, resultava assaz difícil, de modo que julgava que esta discussão devia ser aprazada:

Parece que este artigo devia ficar adiado, porque tem conexão com o outro, porque, por exemplo, se admitirem como cidadãos Portugueses os filhos dos estrangeiros, é preciso depois combinar se os filhos dos Protestantes criados na Religião de seus pais hão de obrigar-se à força a seguirem a Religião Católica; ou se se devem excluir da sociedade. Temos Portugueses nas possessões da África com diferentes seitas, ora se todos estes homens são tidos por vassalos Portugueses, é necessário ver se

\footnotetext{
${ }^{31}$ DCGECNP. Sessão do dia 3 de agosto de 1821, p. 1772.
}

${ }^{32}$ DCGECNP. Sessão do dia 3 de agosto de 1821, p. 1773. 


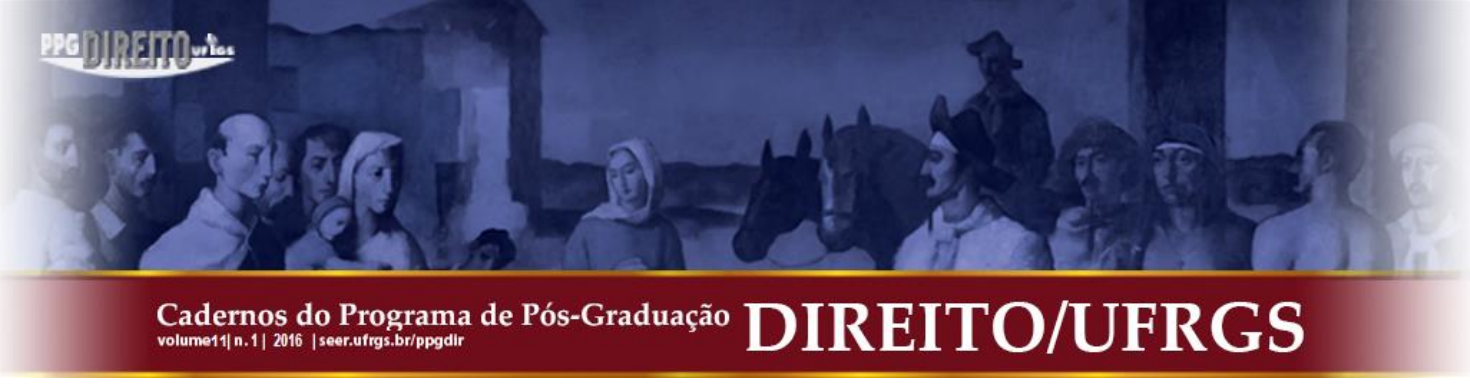

havemos de prescindir deles serem Portugueses todos, ou se havemos de prescindir da Religião ${ }^{33}$.

É evidente que o deputado não pretendia pôr à prova o nível de tolerância como se infere de sua seguinte intervenção, mas traz uma alerta interessante sobre o conflito entre declarar cidadão aos estrangeiros e excluir da cidadania pela declaração de que fosse a religião oficial a Católica Romana.

Uma posição muito mais sensata, defendeu o Sr. deputado Castello Branco, um eclesiástico, que pensava ser tarefa difícil a posição de legislador ao ter que conciliar as leis políticas com as matérias religiosas:

Nós somos Legisladores políticos, e, entretanto somos Legisladores políticos de uma nação que professa, e tem jurado professar a religião Católica Apostólica Romana; por consequência incumbe-nos uma grande obra, e vem a ser conciliar as leis políticas, e as que houvermos de fazer, com essa mesma religião, conciliar os interesses políticos da nação, que por uma parte somos obrigados a promover, com essa mesma religião, que por outra parte somos obrigados a sustentar intacta; a obra algum tanto é dificultosa, mas tudo se pode conciliar ${ }^{34}$.

Entretanto o mesmo deputado via algo de dificuldade naquela tarefa de conciliação de leis políticas com as matérias religiosas, "principalmente quando já vi enunciar uma lei penal neste mesmo Congresso; e vinha a ser que todo aquele que não abraçasse esta religião não poderá ser cidadão" ${ }^{35}$. Opinava o mesmo deputado que este princípio vai chocar-se em sua integralidade aos princípios políticos: "não dá lugar na Constituição a admitir no nosso grêmio cidadãos estrangeiros, quando eles se acharem nas circunstancias em que a Constituição os admite" ${ }^{36}$. E aceita que é um ponto de discussão política muito interessante, e que ninguém pode desentender-se das vantagens do assunto:

Ora este estrangeiro que nós vamos admitir podem ter sido criados em outra religião. Devemos nós obrigá-los a largar a religião de seus pais? Nós quereríamos exclui-lo do nosso seio? Iriamos pôr uma barreira entre nós, e todos os cidadãos para admitir aqueles estrangeiros que podem aumentar a nossa população, a nossa indústria, os interesses da nação, as forças da sociedade? Nós iriamos cortar pela raiz todos os bens que dali pode resultar à sociedade ${ }^{37}$.

\footnotetext{
${ }^{33}$ DCGECNP. Sessão do dia 3 de agosto de 1821, p. 1773.

${ }^{34}$ Ibidem.

${ }^{35}$ Idem. p. 1774.

${ }^{36}$ Ibidem.

${ }^{37}$ Idem. p. 1774.
} 


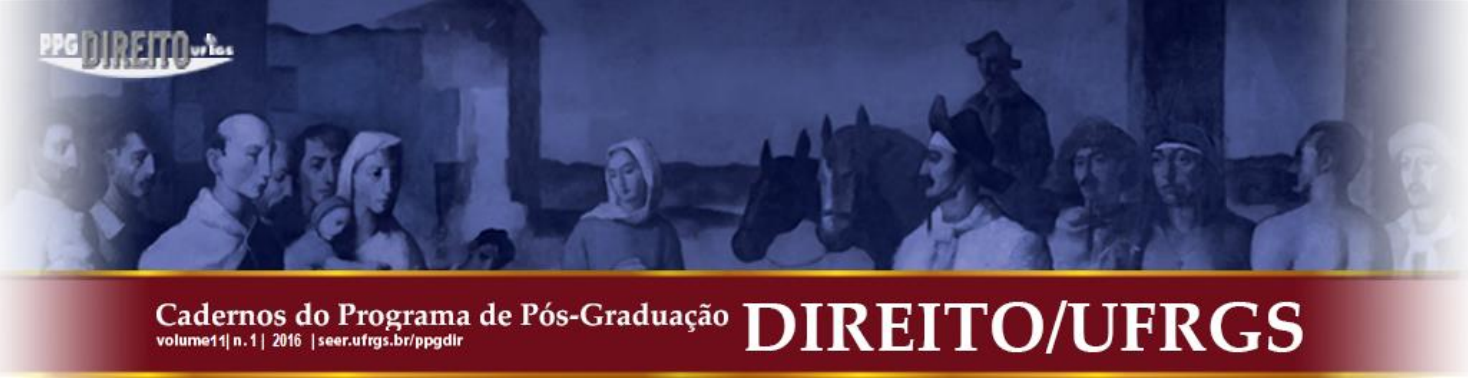

Vai declarar o mesmo deputado que intui das declarações dos ilustres membros da Assembleia, aquelas afirmações que fez mais acima. Ademais, explica que ainda que seja ministro da mesma igreja a que se atribuí a condição de religião do Estado, isso não lhe tira a consciência de que também é um legislador designado para desempenhar as funções a que foi chamado pela Nação. Assim que, nem todos os deputados estavam seguros de que a intolerância religiosa, que se colidia com os direitos políticos, devesse ser adotada. Ao final ficou aprazada a discussão nesta sessão acerca do art. 25.

Na sessão do dia 6 de agosto de 1821, as discussões sobre se se devia adotar ou não a tolerância religiosa e a liberdade de consciência foram muito duras. A primeira e a segunda parte do artigo 25 foram bastante debatidas. Na primeira parte, onde se declarava a Religião da Nação portuguesa a Católica Apostólica Romana suscitava dupla discussão: primeiro, que decretar a liberdade de consciência ${ }^{38}$ e não estabelecer como fé protegida - a Católica - iria contra o mandato recebido pelos deputados se constituía em um problema; posto que juraram o estabelecido nas Bases da Constituição que manteria a Religião Católica. E em segundo lugar, se se devia tratar a matéria religiosa, principalmente sobre a tolerância religiosa concedida aos estrangeiros, no âmbito constitucional ou em lei regulamentaria. Ao que se refere à segunda parte do artigo, no qual se admite a tolerância religiosa aos estrangeiros, as discussões iriam no sentido de que se havia atribuído já nos Tratados de 1810 com Inglaterra a liberdade de todos os cultos, por tanto, não era necessário discutir o tema ${ }^{39}$. Por outro lado, muitos deputados, principalmente o bispo de Béja, opinavam que não se admite a liberdade de consciência aos portugueses ${ }^{40}$, e se estes mudassem de religião se lhes deviam punir com a perda dos direitos de cidadão, afirmação que foi contestada por outros deputados. A evocação

\footnotetext{
${ }^{38}$ DCGECNP. Sessão do dia 6 de agosto de 1821, p. 1803. O deputado Trigoso afirmava que não se devia ser nem totalmente intolerante nem completamente tolerante, e ademais afirmava: "Os Índios devem ser catequisados, e ainda que sejam sujeitos ao império português a Constituição mesma no artigo 180, manda prover a sua conversão, e civilização. Os espanhóis têm índios nas suas Américas, e apesar disto os espanhóis decretaram que a Religião Católica Apostólica Romana era a única do país. Em quanto aos estrangeiros nós temos tido estrangeiros que tem filhos e que se tem naturalizado; nada mais resta que continuar-se a seguir acerca deles, o que até agora se tem praticado".

${ }^{39}$ DCGECNP. Sessão do dia 6 de agosto de 1821, p. 1804. Deputado Soares Franco: "Apoio, pois, o artigo como está, e tiraria a palavra particular, dizendo - o exercício de seus respectivos cultos. - O tratado de 1810, dizcom tanto que não façam prosélitos, e se ofenda a tranquilidade do Estado - ela está consignada nos tratados; por consequência, não é preciso por ora, que se estabeleça; e quando for preciso não tira que ela seja posta numa lei constitucional; torno a repetir, que não sou do voto que se permita a tolerância, ou o mudar de Religião; porque em fim acaba de jurar-se a Religião Católica que é a verdadeira (...)”.

${ }^{40}$ Idem. p. 1805. Declara o bispo de Béja, deputado das Cortes que: "Do espirito do artigo 25 da Constituição se conclui, que aqueles Portugueses que abandonarem a Religião dominante, ou negarem algum dos seus dogmas não devem gozar dos direitos de cidadão”.
} 


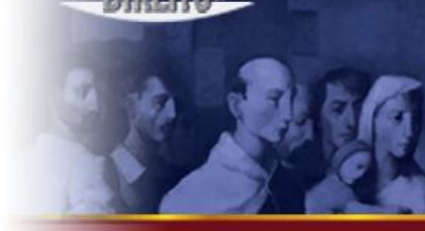

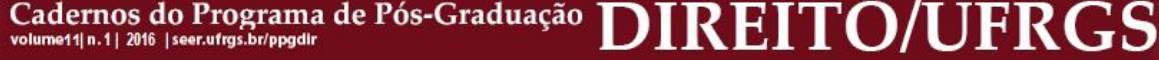

à história de Portugal era algo recorrente nas discussões, cheias de exemplos de tolerância, e das desgraças advindas, quando se optou pela intolerância, com a expulsão dos judeus e mouros. Exemplifica o deputado Franzini com um fato da história recente (em sua época) de Portugal de tolerância, quando diz:

\begin{abstract}
Nada direi a favor da tolerância depois de se ter expendido esta matéria tão sabiamente; entretanto vou a fazer uma reflexão que adoptada esta doutrina em contrário retrogradaria o sistema de princípios liberais; porque nunca vi que em Portugal deixassem de ter empregos públicos homens mesmo de outra religião; e ainda há pouco nós acabamos de ver um Vice-Rei de Portugal Protestante. Agora o decretar que qualquer ficaria excluído de todos os empregos uma vez que não praticasse a Religião Católica, seria no meu modo de pensar o mais absurdo ${ }^{41}$.
\end{abstract}

Assim que muitas foram as vozes a favor da liberdade de consciência e pela tolerância religiosa, com sobrados argumentos históricos, tanto da tradição portuguesa de ser tolerante como das nações que ao momento eram exemplo de adoção da tolerância e a prosperidade que depreendia desta atitude do Estado, tais como Inglaterra, Estados Unidos da América, Holanda, França etc. Mas, em dois momentos chamou a atenção sobre as populações autóctones; uma na fala do deputado Trigoso e outra na fala do deputado Borges Carneiro. Nos conta Cristina Nogueira, em análise a estes mesmos documentos, que "ademais da hipótese, ambiciosa, da liberdade religiosa, duas outras orientações surgiram nas Cortes vintistas. Uma delas fui a tolerância religiosa, pela qual se devia instituir a tolerância relativamente aos protestantes e aos infiéis ou 'Étnicos', Mouros e Judeus ${ }^{42}$. Às outras orientações, pelo contrário, se manifestou favorável a exclusão das populações nativas, havendo sido expressamente assumida por um deputado cuja opinião era de que as opções religiosas deviam valer como critério de acesso à cidadania portuguesa"43.

Estes debates continuaram na sessão do dia 8 de agosto para definir mais especificamente a liberdade de consciência para os portugueses e se era motivo de exclusão da cidadania que o português abandonara a religião católica. $O$ primeiro deputado a manifestar-se fui o Sr. Pereira do Carmo que estava a favor de que se concedesse aos

\footnotetext{
${ }^{41}$ DCGECNP. Sessão do dia 6 de agosto de 1821, p. 1805. Aqui o deputado se refere a Lord Beresford, com a expulsão dos franceses e o domínio britânico em Portugal enquanto a Rainha D. Maria I e o Príncipe Regente se encontravam no Rio de Janeiro.

${ }^{42}$ Idem. p. 1801. Dep. Borges Carneiro: "Isto digo dos Protestantes, a quem chamamos hereges, é aplicável aos infiéis, quero dizer Étnicos, Mouros e Judeus. Não basta proscrever-nos a ideia de obrigá-los à força, e com coação física a seguir a nossa Religião".

${ }^{43}$ SILVA, Cristina Nogueira. op. cit., p. 43 e 44. DCGECNP. Sessão do dia 3 de agosto de 1821, p. 1773, Dep. Antônio Pereira.
} 


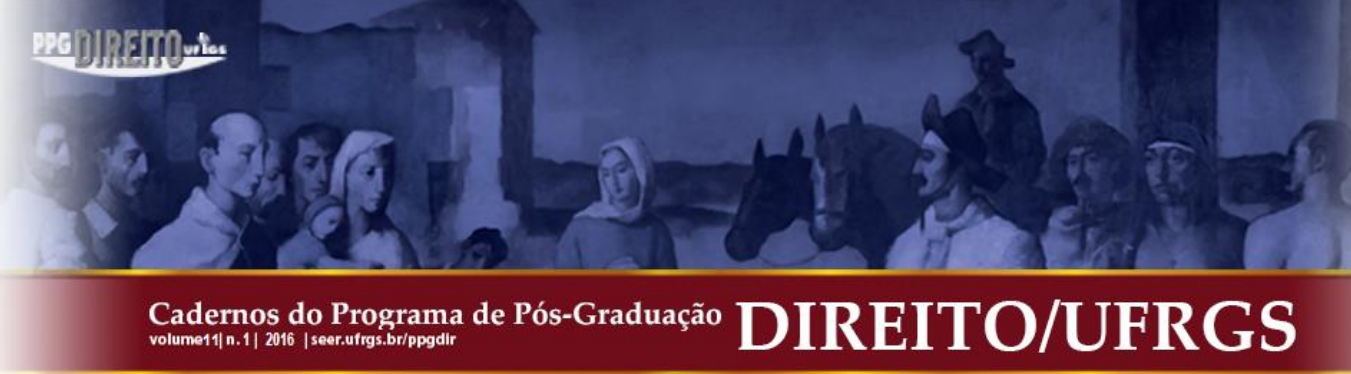

estrangeiros a tolerância civil. Logo outro deputado, o Sr. Bispo de Béja, suscitou a questão sobre os portugueses que abandonassem a religião católica, se se devia considera-los cidadãos com o gozo de todos os direitos ou não. Também, explica que não se devia confundir tolerância civil com proteção. E explica: a primeira, consistiria em não perseguir aos delitos de consciência; a segunda, consistiria em defender à religião dos insultos. Por tanto, se aplica a pena de perda dos direitos políticos aos portugueses que abandonassem à fé dominante. E, a cima de tudo, levanta outra questão fulminante: se aquele que abandona a fé católica não está privado da cidadania, tão pouco estaria o rei que abandone a fé de sua $\operatorname{coroa}^{44}$. Para corroborar as ideias um tanto reacionárias do bispo, pede a palavra o deputado Pinheiro de Azevedo, que era contrário a que se declarasse direta ou indiretamente a liberdade de consciência. Que seria o mesmo que decretar que qualquer um que não siga a religião dominante possa ser cidadão português. Argumenta, outrossim, que estaria contra do que estava estabelecido nas Bases Constitucionais. E segue suas imprecações dizendo que as nações que decretaram a liberdade de consciência eram porque já tinham estas mesmas liberdades antes de decretar, e cita os exemplos dos Estados Unidos da América, Holanda e Inglaterra. Compara também a situação dos portugueses a dos espanhóis, que não decretaram a liberdade de consciência: "A liberdade de consciência iria encontrar a opinião pública; causar grandes desgostos à nação, e desacreditar o congresso" ${ }^{45}$.

$\mathrm{Na}$ mesma sessão do dia 8 de agosto, outro deputado, o Sr. Moura, se pronuncia que se deve "combinar a liberdade de pensar com os interesses políticos do Estado" 46 . Ainda mais, defende que o artigo 25 seja aprovado sem quaisquer alterações. E segue dizendo que a liberdade de consciência, ou a liberdade de pensar e de adotar qualquer opinião em matéria religiosa, é um direito imprescindível e ilimitado que ninguém pode contestar. Enquanto que a liberdade de culto pode ser perfeitamente objeto de uma legislação específica. Está convencido, ademais, que é a mais pura verdade que proscrever o culto público de todas as religiões e adotar um só culto como dominante e substituir a intolerância civil pela intolerância religiosa não seria nem conforme à razão, nem à justiça, nem à política. Sua

\footnotetext{
${ }^{44}$ DCGECNP. Sessão do dia 6 de agosto de 1821, pp. 1818 e 1819, Deputado Sr. bispo de Béja.

${ }^{45}$ DCGECNP. Sessão do dia 6 de agosto de 1821, p. 1819, Deputado Pinheiro de Azevedo.

${ }^{46}$ DCGECNP. Sessão do dia 8 de agosto de 1821, p. 1819, Deputado Moura.
} 


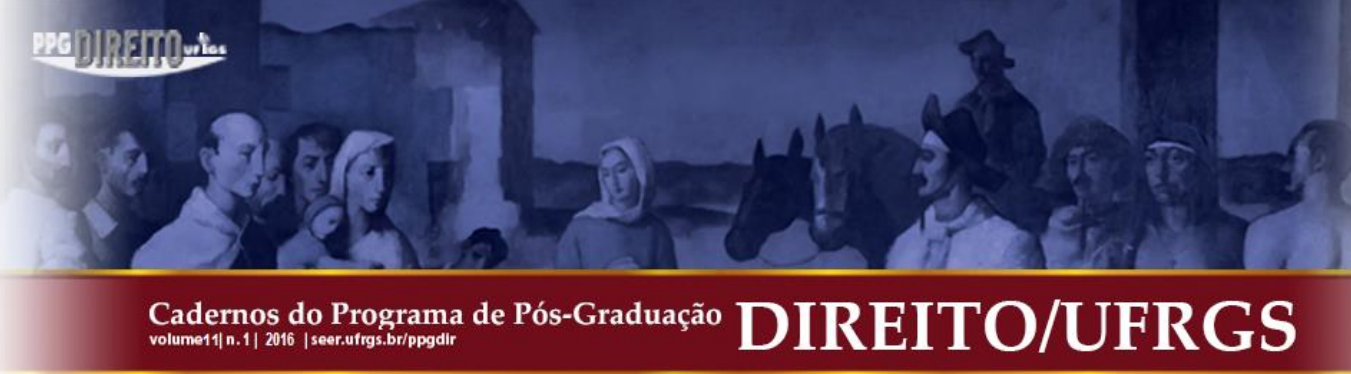

receita para o que denomina "indifenrentismo religioso"47 seria proclamar a tolerância de todos os cultos.

Em réplica àquelas ideias, o deputado Correa de Seabra é da opinião de que a tolerância religiosa não deveria ser sancionada em um artigo constitucional. E argumenta que ao decretar dita tolerância não estava na delegação que a Nação lhes havia concedido e jurada nas Bases que estabelecia uma religião de Estado. Entretanto, vai admitir que se pode transigir sobre este tema no futuro, com outras noções, tendo a tolerância por vantagem. É da mesma opinião do deputado Pinheiro Azevedo, de que Portugal estaria na mesma situação que Espanha, que não sancionou a tolerância, e as nações que o fizeram, era porque se achavam em umas mui diversas circunstâncias. Assim que, para este deputado, devia-se admitir a necessidade de que viessem estrangeiros para povoar o Brasil, e, portanto, não se devia ser intolerante com estes. Vai dizer, ainda mais, que a procuração dada pela Nação mandava manter à religião católica, sem admitir outra religião para os portugueses. E mandava excluir dos direitos políticos a todos os que não professassem a religião católica ${ }^{48}$. Este deputado não via nenhuma violência ao retirar os direitos políticos aos que não fossem católicos, e cita como exemplo a impossibilidade de nomear para magistrado o indivíduo que não esteja licenciado, e não vê nisso violência alguma ou coação aos sentimentos religiosos de cada um. E faz referência de seu relativismo às populações autóctones do ultramar:

\begin{abstract}
Vejo objetar contra isso, que nós já de fato temos nos Estados Ultramarinos cidadãos que são gentios, e que não devemos agora por esta clausula da Constituição excluilos da nossa sociedade; porém não reconheço por cidadãos Portugueses os Tapuias bravios do Brasil, ou os gentios da Costa da África: temos quando muito uma certa dominação sobre os que estão aldeados, que só dura enquanto eles querem. E se se fala desta desgraçada gente deve ser só por nos lembrarmos de cuidar com todo o zelo em os catequizar, e tratar com toda humanidade. Só a religião pode abolir na Europa a escravatura, adoçar os costumes bárbaros do Norte, e melhorar os costumes corrompidos dos romanos: só ela, pregadas por ministros pios e zelosos, é quem tem podido tirar da barbárie os Tapuias e Africanos que se tem civilizado, e poderá civilizar o resto se nisso se puser o devido cuidado. Não é com a tolerância, mas só com o ensino da religião que os havemos de habilitar para serem cidadãos portugueses; porque só assim os podemos pôr em estado de civilização; sem o que não podem fazer parte de uma sociedade civil, em que haja ideias de justiça, amor da pátria, e obediência às leis ${ }^{49}$.
\end{abstract}

\footnotetext{
${ }^{47}$ Ibidem.

${ }^{48}$ Enquanto se propugnava por excluir aos portugueses que abandonassem a religião dos direitos políticos, os cidadãos portugueses não podiam ser expulsos do Reino senão em virtude de lei ou sentença criminal. Esta afirmação se pode encontrar em LOPES PRAÇA. Estudos sobre a Carta Constitucional de 1826 e Acto Adicional de 1852. Coimbra: Imprensa Literária, 1878, p. 158.

${ }^{49}$ DCGECNP. Sessão do dia 8 de agosto de 1821, p. 1821, Deputado Correa de Seabra.
} 


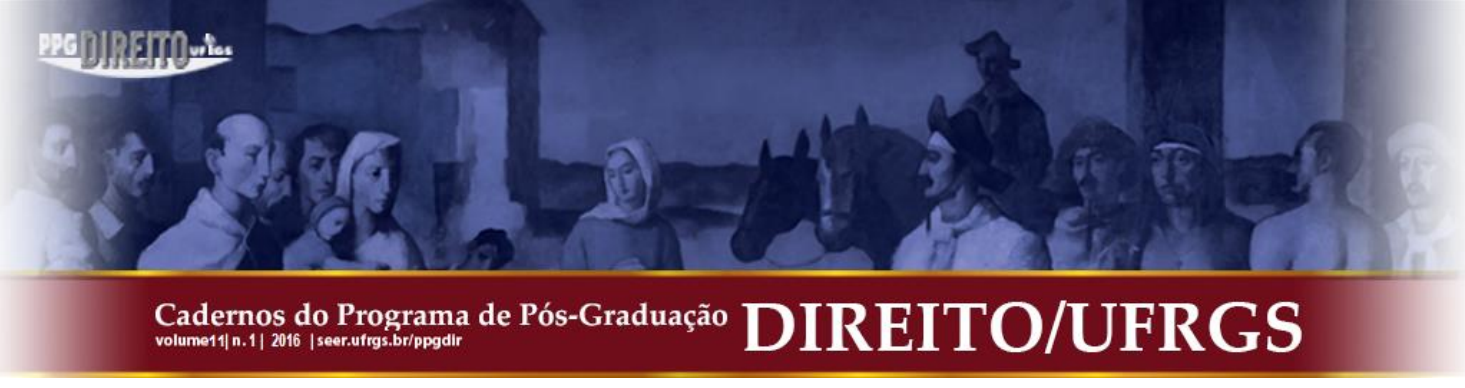

Assim que deduzimos da intervenção do deputado que seu conceito de cidadania era bastante restringido para o ultramar, e passava também por processos civilizacionais que incluiriam tanto a educação como a religião; esta enquanto meio ultimo para adquirir a cidadania, fazendo parte da sociedade civil, imbuídos da ideia de justiça, de amor à pátria e obediência às leis como bem prescrevia o artigo 19 da Constituição vintista.

Então, nas acaloradas discussões, entre o deputado Abade de Medrões, que irritado com a prolixidade das questões e extensões das intervenções, e seus colegas deputados, resolve sintetizar as questões na ordem do dia na Assembleia constituinte:

Pregunta-se em primeiro lugar, se os portugueses que não professarem a religião católica, devem gozar dos direitos dos cidadãos: em segundo lugar, se as nações estrangeiras se há de conceder a tolerância de culto, segundo as diferentes religiões: em quarto lugar (não disse a terceira), se é aqui lugar próprio para estabelecer este artigo: e ultimamente, se é melhor, suprimir inteiramente o artigo ${ }^{50}$.

Conclui o referido deputado que ao consentir aos estrangeiros o culto de sua religião, é antes que nada, uma providência política e que pouco tem que ver com outras questões de ordem religiosa. E diz assim certamente pensando nos Tratados de 1810, que foram mencionados muitas vezes nas sessões das Cortes.

O Sr. Deputado Vaz Velho argumenta que está a favor de que no caso de troquem de religião, aos portugueses se lhes devem privar dos direitos políticos. Para ratificar seu posicionamento faz referência ao mandato concedido pela Nação no sentido de proteger à religião dominante ${ }^{51}$. Neste sentido vai manifestar-se o deputado Fernandes Thomaz, que levanta a questão de permitir aos portugueses a tolerância religiosa, e pensa que a questão não está suficientemente debatida para seguir para a aprovação. No que estava de acordo o bispo de Bejá. Em seguida o deputado Moura volta à carga dizendo que é contrário a privar dos direitos de cidadão aos portugueses que mudem de religião.

Também outro deputado, o Sr. Guerreiro, suscita algumas questões no sentido das discussões. Deste modo, se declara contrário a que se prive aos portugueses que abraçarem outra religião, que não seja a do Estado, de seus direitos políticos; o que considera um ataque à liberdade do cidadão proibir a mudança de religião. Admoesta a seus companheiros que é

\footnotetext{
${ }^{50}$ Idem. p. 1821, Deputado Sr. Abade de Medrões.

${ }^{51}$ Idem. p. 1822, Deputado Vaz Velho.
} 


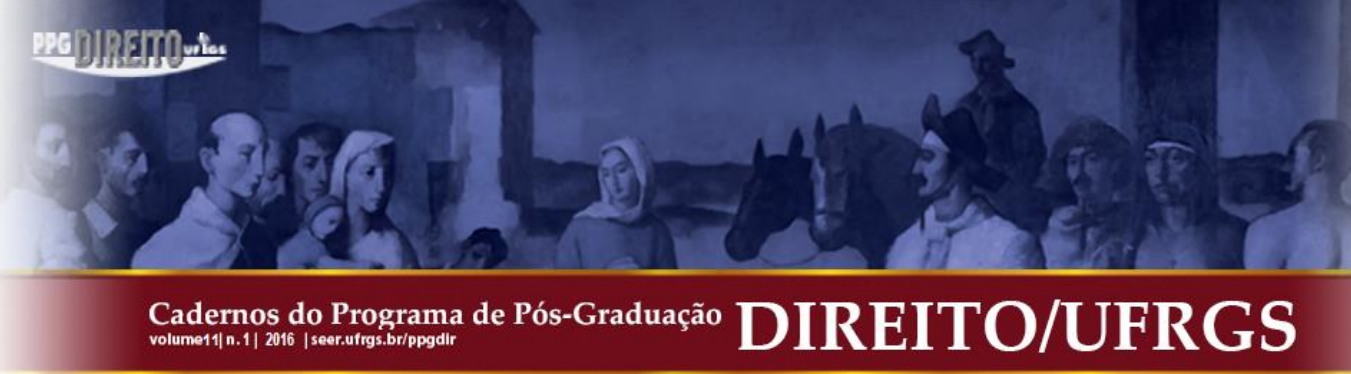

necessário sancionar a liberdade de culto ainda que não seja o da religião dominante. E assim termina dizendo que:

Concluo daqui que é absolutamente necessário decidir-se esta questão; o interesse da sociedade, e o direito natural exigem que se estabeleça indistintamente a liberdade de exercício particular de qualquer culto religioso. O meio de estabelecer isto é muito fácil, pois basta tirar somente a palavra Estrangeiros; concebendo-se o artigo desta maneira: permite-se o exercício particular de qualquer outro culto religioso ${ }^{52}$.

Portanto, este deputado estava a favor da implantação da liberdade de consciência no Império português. Mas, nesta linha de discussão, o deputado Sousa Magalhães vai dizer que os redatores do artigo discutido não quiseram estabelecer a intolerância. Ademais, faz referência à concordata firmada entre a Santa Sé e Napoleão Bonaparte em 1801, e na qual, por ser interessante à França a boa convivência política com os protestantes, estes seriam tolerados, ainda que a religião católica permanecia como religião protegida da Nação. E era de opinião que o artigo devia passar tal qual se encontrava nas Bases da Constituição. De maneira que para os deputados, em sua maioria, se dava o entendimento de que os estrangeiros seriam alijados da cidadania por ter outra religião:

Que não se segue da disposição do parágrafo, nem se pode seguir, de modo nenhum, que seja necessário a um estrangeiro mudar de religião para obter carta de naturalização ${ }^{53}$.

A isto contesta o deputado Guerrero:

É certo que em nenhuma parte do projeto da constituição se opõe obstáculo ao concedimento de semelhante carta; mas se em alguma das legislaturas eu fosse deputado, e um estrangeiro me pedisse carta de naturalização, eu não a podia conceder, tendo sido aprovado este parágrafo; e a razão é clara; porque estabelecendo-se que fica permitido aos estrangeiros o exercício particular de seus respectivos cultos, logo o contrário sensu está proibido aos cidadãos portugueses, por paridade da razão não deve ser permitido ou admitir-se qualquer no número de cidadãos portugueses sem professar a religião católica ${ }^{54}$.

Para rebater as críticas sobre os impedimentos para que os estrangeiros conseguissem a carta de naturalização, o deputado Moura alude ao art. 22 da Constituição, onde figuravam os requisitos para que um estrangeiro alcançasse a naturalização no Império português.

$\mathrm{O}$ art. 22 diz que para se conceder carta de naturalização aos estrangeiros concorrerão três requisitos; nenhum deles é a religião; logo os mais artigos da

\footnotetext{
${ }^{52}$ Idem. p. 1822-1823, Deputado Guerreiro.

${ }^{53}$ Idem. p. 1823, Deputado Moura.

${ }^{54}$ Idem. p. 1824, Deputado Guerreiro.
}

Cadernos do Programa de Pós-Graduação em Direito PPGDir./UFRgS | Edição Digital | Porto Alegre | Volume XI | Número 1 | 2016 | P.371-396 


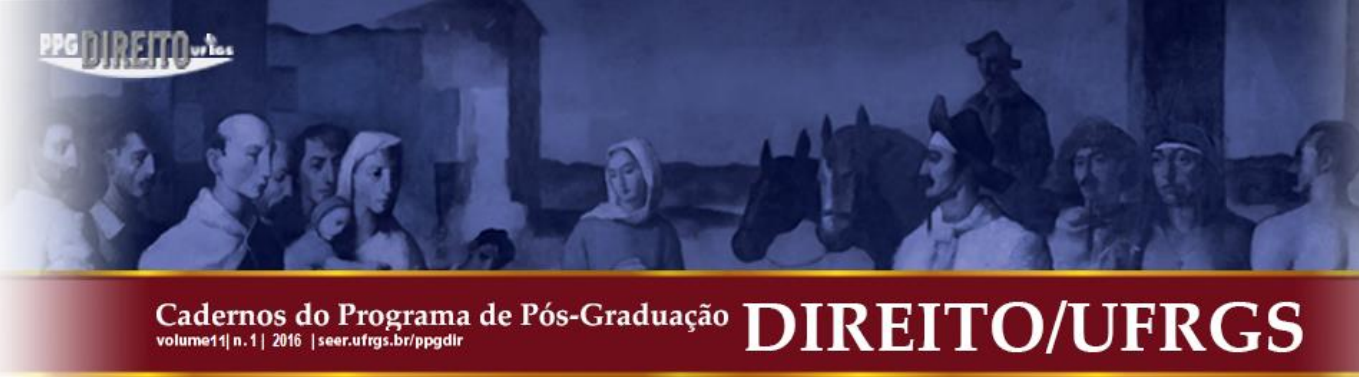

Por mais sensata que parecesse a proposição do deputado, o artigo foi submetido à votação, por encontrar-se já bastante discutido, segundo o presidente das Cortes, e foi aprovado tal como estava proposto nas Bases da Constituição.

De tal artigo se abstrai a tolerância religiosa aos estrangeiros sem tratar dos pormenores espinhosos que viemos tratando. Por força dos Tratados de 1810 uma matização ao princípio da intolerância religiosa, imposto pelo modelo gaditando, espanhol, alcançou a Constituição de 1822. Embora aqueles tratados impusessem a liberdade de consciência ao governo e territórios do Império Luso, uma parte penal foi manejada como instrumento de contenção ao proselitismo no universo católico do Império. Se bem é verdade que o mesmo se dava, através do Princípio da reciprocidade dos tratados, no Império britânico, ou seja, em ambiente protestante.

\section{CONCLUSÃO}

Há que se ressaltar em toda esta discussão que aos estrangeiros se lhes permitia, depois de conseguida a carta de naturalização, votar nas eleições primárias, mas estava vetado a que estes pudessem apresentarem-se para deputados, por exemplo. Entendia-se assim que o português que adotasse outra religião perderia seus direitos políticos de cidadão ${ }^{60}$. Portanto, todos os outros naturais do Império eram potencialmente cidadãos, desde que abraçassem a fé católica, ainda que isso não estivesse explícito no texto constitucional, se depreende da leitura do art. 19 onde se estabelecia a obrigação, como um dos deveres dos cidadãos portugueses, de professar a religião católica. No texto final da Constituição de 1822, aos estrangeiros estava garantida a liberdade religiosa, como já prescrevia o Tratado de 1810, no entanto, não ficou muito bem claro si este ao obter a cidadania portuguesa devesse abdicar de sua religião, ou os filhos destes nascidos no Império português, mas educados na religião protestante. $\mathrm{O}$ Tratado de 1810 vigorou até a dissolução do Reino Unido de Portugal, Brasil e Algarves e muito mais além, posto que foi incorporado na década de 1820 ao ordenamento do Brasil independente. Como pudemos constatar, os dispositivos penais previstos no âmbito do Tratado e no âmbito de um Estado confessional tiveram matizes ideologizados - econômicos se se prefere introduzidos para que o fator não fosse absoluto. Mesmo no ambiente da Assembleia Constituinte, o Parlamento vai discutir a imposição de um dispositivo penal no texto da

\footnotetext{
${ }^{60}$ Para ampliar mais estas discussões leiam-se em SILVA, Cristina Nogueira da. op. cit., p. 45 e ss.
} 


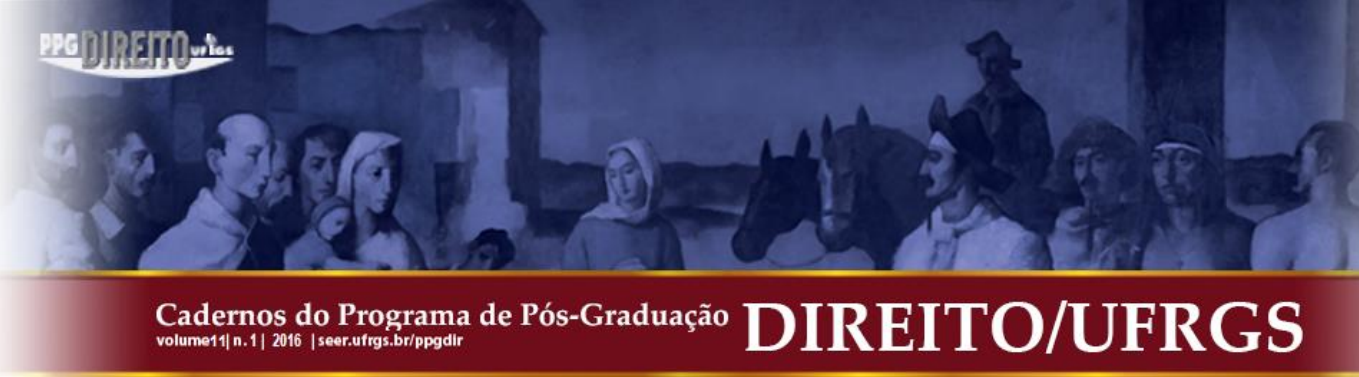

Constituição, que previa que o português que abandonasse a religião oficial do estado seria punido com a perda da cidadania. O Tratado traz um elenco de normas que disciplinam a vida social e suas interações com o ambiente social católico, como também normas penais para coibir determinadas atitudes proselitistas, por exemplo. Houve vozes no Parlamento pedindo, por conveniência, a liberdade de consciência, e em parte foram acatadas quando se permite aos estrangeiros a liberdade de culto no império, ademais, porque já havia antes sido permitido através dos referidos tratados que assina o governo português com a Grã-Bretanha.

\section{REFERÊNCIAS}

BRASIL. Carta de lei de 26 de Fevereiro de 1810. Ratifica o Tratado de Amizade e Aliança entre o Príncipe Regente de Portugal e El'Rey do Reino Unido da Grande Bretanha e Irlanda. Rio de Janeiro: Imprensa Nacional, 1810.

Carta lei de 26 de fevereiro de 1810. Ratifica o Tratado de Comercio e Navegação entre o Príncipe Regente de Portugal e El'Rey do Reino Unido da Grande Bretanha e Irlanda. Rio de Janeiro: Imprensa Nacional, 1810.

CASTRO, Zília Osório de. Cultura e Política. Manuel Borges Carneiro e o Vintismo. v. II. Lisboa: Instituto Nacional de Investigação Cientifica, Universidade Nova de Lisboa, 1990.

CATROGA, Fernando. Em nome da Nação. In: CATROGA, F.; ALMEIDA, Pedro Tavares de (Cords.). Res Pública: Cidadania e representação política em Portugal, 1820-1826. Lisboa: Biblioteca Nacional de Portugal, Assembleia da República, 2010.

. Entre deuses e césares. Secularização, laicidade e religião civil. $2^{\mathrm{a}}$ Edição. Coimbra: Editora Almedina, 2010.

COELHO, Manuel Trindade. Manual politico do Cidadão portuguez. Lisboa: Parceria A M. Pereira, 1906.

FRANÇA. ASSEMBLEIA NACIONAL. Declaration de Droits de L'Homme et du Citoyen. Paris: 1789. 


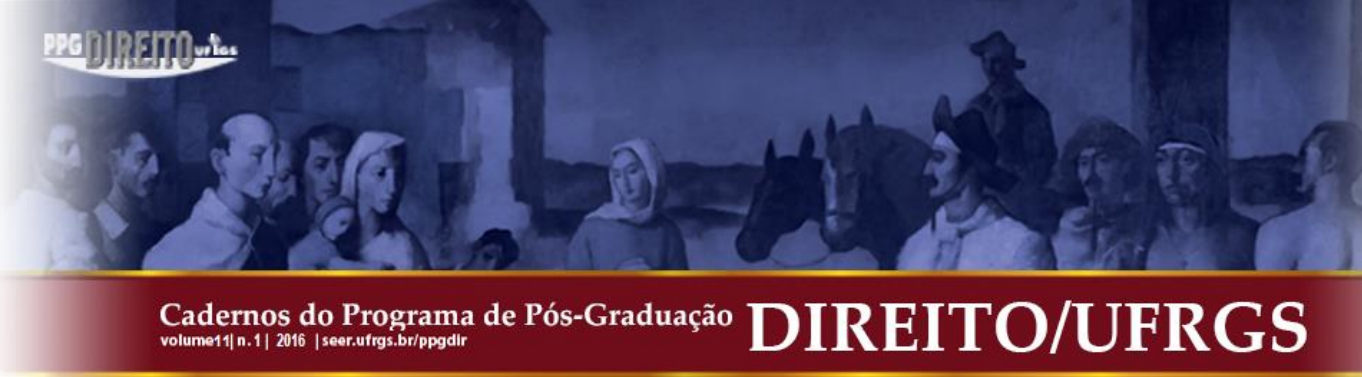

FANTASIAS Constitucionaes, seguidas por algumas reflexões, da Razão, e da Experiência. Publicadas por um Lusitano Filantropo. Lisboa: Imprensa Nacional, com licença da Comissão de Censura, 1821.

FERREIRA, Silvestre Pinheiro. Breves observações sobre a Constituição Política da Monarchia Portugueza decretada pelas Cortes Geraes Extraordinarias e Constituintes reunidas em Lisboa no anno de 1821. Paris: Rey E. Gravier, 1837. In: HESPANHA, A. M.; SILVA, Cristina Nogueira da (dir.). Fontes para a história constitucional portuguesa. Lisboa: Faculdade de Direito da Universidade Nova de Lisboa, Sitio da Biblioteca Nacional, 2004.

Projeto de Código Político para a Nação Portugueza. Ministro de Estado honorário, sócio da Academia das Sciencias de Lisboa e correspondente do Instituto de França. Paris: Casa de Rey; Gravier; de J. P. Aillaud, 1838.

HESPANHA, Antônio Manuel. A constituição do Império português. Revisão de alguns enviesamentos correntes. In: FRAGOSO, Joao; BICALHO, Maria Fernanda; GOUVÊA, Maria de Fátima (orgs.). O Antigo Regime nos trópicos. A dinâmica imperial portuguesa (Séculos XVI-XVIII). Rio de Janeiro: Civilização Brasileira, 2001.

Guiando a mão invisível. Direitos, Estado e Lei no Liberalismo Monárquico Português. Coimbra: Almedina, 2004.

LOPES PRAÇA. Estudos sobre a Carta Constitucional de 1826 e Acto Adicional de 1852. Coimbra: Imprensa Literária, 1878.

RAMINELLI, Ronald. Império da fé: Ensaio sobre os portugueses no Congo, Brasil e Japão. In: FRAGOSO, Joao; BICALHO, Maria Fernanda; GOUVÊA, Maria de Fátima (orgs.). $O$ Antigo Regime nos trópicos. A dinâmica imperial portuguesa (Séculos XVI-XVIII). Rio de Janeiro: Civilização Brasileira, 2001.

RAMOS, Rui Manuel Gens de Moura. Do direito português da nacionalidade. Coimbra: Coimbra Editora, 1992.

SANTOS, Catarina Madeira. Um governo "polido" para Angola, reconfigurar dispositivos de domínio (1750-c. 1800). Lisboa: Dissertação de doutoramento apresentada à Universidade Nova de Lisboa (Faculdade de Ciências Sociais e Humanas), 2005. 


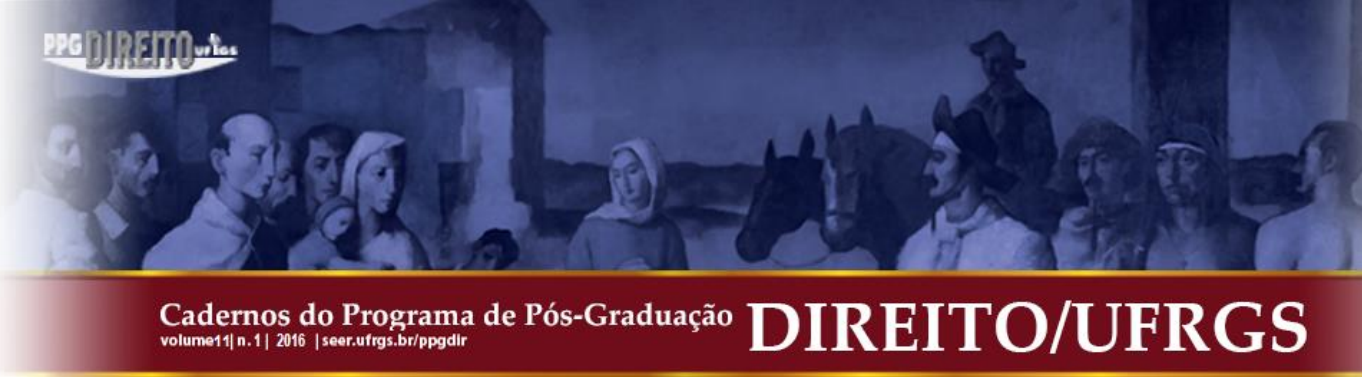

SILVA, Cristina Nogueira da. A cidadania nos Trópicos. O Ultramar no constitucionalismo monárquico português (c. 1820-1880). Lisboa: Dissertação de doutoramento apresentada à Universidade Nova de Lisboa (Faculdade de Direito), 2004.

Liberdade e tolerância religiosa: "portugueses não católicos" no ultramar do século XIX. Historia Constitucional. n. 8, 2007. Disponível em: <http://hc.rediris.es/08/index.html>. Acessado em: 5 de Jan. 2016.

SOBRAL, José Manuel. O Norte, o Sul, a raça, a nação - representações da identidade nacional portuguesa (séculos XIX-XX. v. XXXIX, nº 171. Lisboa: em Análise Social, 2004.

REINO UNIDO DE PORTUGAL, BRASIL E ALGARVES. Diário das Cortes Gerais, Extraordinária e Constituintes da Nação Portugueza. Segundo Anno da Legislatura. Tomo: I. Lisboa: Na Imprensa Nacional, 1821.

Diário das Cortes Gerais, Extraordinária e Constituintes da Nação Portugueza. Segundo Anno da Legislatura. Tomo: II. Lisboa: Na Imprensa Nacional, 1821.

Diário das Cortes Gerais, Extraordinária e Constituintes da Nação Portugueza. Segundo Anno da Legislatura. Tomo: III. Lisboa: Na Imprensa Nacional, 1821.

. Diário das Cortes Gerais, Extraordinária e Constituintes da Nação Portugueza.

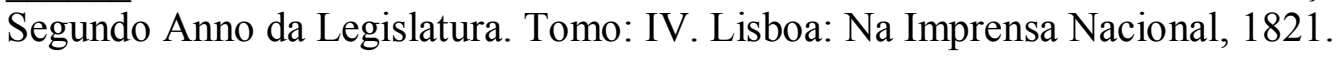

. Diário das Cortes Gerais, Extraordinária e Constituintes da Nação Portugueza. Segundo Anno da Legislatura. Tomo: V. Lisboa: Na Imprensa Nacional, 1822.

. Diário das Cortes Gerais, Extraordinária e Constituintes da Nação Portugueza.

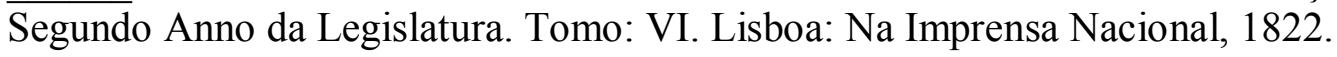

- Diário das Cortes Gerais, Extraordinária e Constituintes da Nação Portugueza.

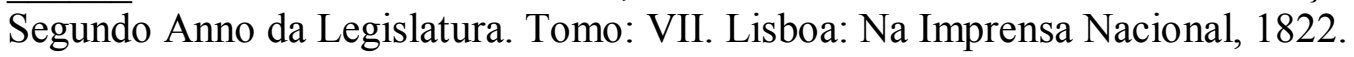

Submissão: $18 / 01 / 2016$

Aceito para Publicação: 26/03/2016 


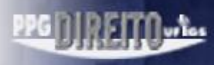

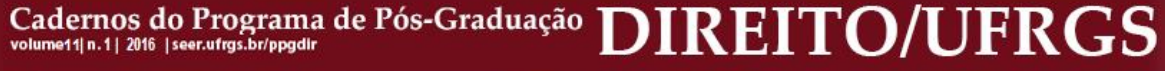

